\title{
Early and middle Holocene environments and Capsian cultural change: evidence from the Télidjène Basin, eastern Algeria
}

\author{
Mary Jackes and David Lubell \\ Department of Anthropology, University of Waterloo, Waterloo ON N2L 3G1, Canada
}

\begin{abstract}
Interdisciplinary investigations from 1973 to 1978 at Aïn Misteheyia and Kef Zoura D, two stratified Capsian sites in the Télidjène Basin, Tebessa Wilaya, Algeria, have shown that palaeoenvironmental changes centred around the 8200 calBP event can be correlated with changes in subsistence and technology traditionally associated with the difference between Typical Capsian and Upper Capsian. We use data from geoarchaeological investigations, invertebrate and vertebrate faunal assemblages, and radiocarbon analyses to characterize the nature and extent of these changes.
\end{abstract}

\section{Resumé}

Les investigations interdisciplinaires entrepris de 1973 jusqu'à 1978 à Aïn Misteheyia et Kef Zoura $\mathrm{D}$, deux gisements Capsiens stratifiés dans le bassin de Télidjène, Wilaya de Tébessa, Algérie, ont montré que les changements paléoenvironnementales concentrés sur l'événement de 8200 calBP peuvent être corrélés avec ceux de la subsistance et de la technologie traditionnellement liées à la différence entre le Capsien typique et le Capsien supérieur. Nous employons les données géoarchéologiques, archéozoologiques et les analyses de radiocarbone pour caractériser la nature et l'ampleur de ces derniers changements.

\section{Keywords}

Capsian, Maghreb, Holocene, cultural stratigraphy, palaeoenvironmental change

Published in the African Archaeological Review Volume 25: 41-55

Special issue edited by N. Barton, A. Bouzouggar and D. Lubell on "Modern Human Dispersals, Environments and Cultural Change in the Late Pleistocene of Northwest Africa”

The original publication is available at www.springerlink.com DOI:10.1007/s10437-008-9024-2 


\section{Capsian stratigraphy}

When Vaufrey (1936) published his typological study on Capsian stratigraphy, he had only the data from Relilaï rockshelter upon which to argue that Typical Capsian (Capsien typique) was older than Upper Capsian (Capsien supérieur). Radiocarbon dating in the 1960s and 70s led Camps (1968, 1974, 1975; Camps et al. 1968) to construct a chronology which appeared to show a prima facie case for contemporaneity of the Typical and Upper Capsian. Grébénart's reexcavation and re-analysis of Relilaï and several other sites led him to conclude (1976: 296) that a unilineal sequence of Typical Capsian-Upper Capsian was no longer tenable. However, as additional radiocarbon dates became available (Close 1980, 1984, 1988) and new syntheses were attempted (Lubell et al. 1984, 1991; Sheppard and Lubell 1990), it seemed that Camps and Grébénart might not be correct. Careful excavation in the 1970s of two Capsian escargotières in the Télidjène Valley (Fig. 1), the open-air site at Aïn Misteheyia (hereafter AM) and the rock shelter at Kef Zoura D (hereafter KZD), provide dated stratigraphic sequences in which the typological and technological changes in lithic assemblages characteristic of the distinction between Typical Capsian and Upper Capsian are most parsimoniously interpreted as a chronological sequence correlated with changes in palaeoenvironmental conditions and subsistence strategies (Lubell 1984; Lubell et al. 1975, 1976, 1982-83).

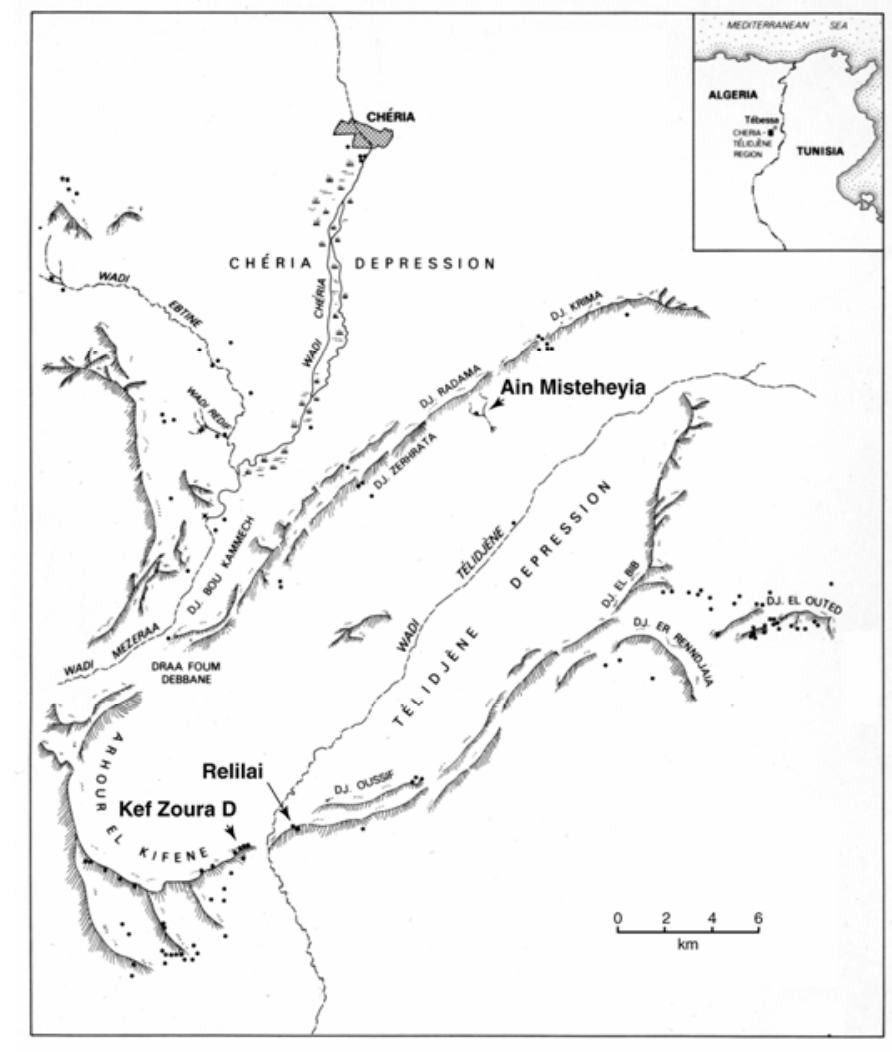

Figure 1 Map of the Télidjène Basin, Algeria showing location of sites discussed and major geographic features. Modified from Lubell et al. (1976). 
At both sites, there is evidence for the introduction of the pressure technique for blade and bladelet production, first recognized by Tixier at Aïn Dokkara (1976). Analyses by Sheppard (1987, 1988), using a limited suite of radiocarbon analyses, showed that the introduction could be dated to ca. $8000 \mathrm{BP}^{1}$. Primarily on typological grounds, Sheppard considered the entire sequence at AM to be Upper Capsian - a situation parallel to Medjez II (Camps-Fabrer 1975). However, at KZD, he found clear evidence for a stratigraphic succession from an earlier assemblage of Typical Capsian to a later one of Upper Capsian.

Rahmani's (2003, 2004a, 2004b) studies of a larger series of Capsian assemblages using chaîne opératoire methodology, show that the difference between Typical and Upper Capsian is primarily technological and chronological rather than typological, and that the two occur in sequence at several sites. Based on a detailed analysis of all reliable radiocarbon dates, she dates the boundary between Typical and Upper Capsian to ca. 8000 200 BP.

We propose here that there is continuity across the Typical to Upper Capsian boundary, the transition between them being intensified in response to climatic variation around 8000 calBP. In fact there is very little reason to consider that there was significant cultural or biological discontinuity in the Maghreb in the late Pleistocene and early Holocene.

The only clear evidence for introduction of outside elements in the Maghreb during the early and middle Holocene may be the occurrence of possibly domestic fauna at Grotte Capéletti (Roubet 1979) and Haua Fteah (Klein and Scott 1986); however in both instances this would be late in the sequence and associated with assemblages belonging to the Neolithic of Capsian Tradition or other variants. Despite intriguing similarities between Iberomaurusian lithic assemblages and contemporary ones from the Nile Valley (Close and Wendorf 1989, with references), bioarchaeological studies of the human populations involved (Groves and Thorne 1999; Irish 2000) do not provide clear answers to questions of connection. The situation today remains much the same as when we discussed it in 1984 and again in 1990, and recent work on the Iberomaurusian (Barton et al. 2008; Hachi 1996, 1997; Mikdad and Eiwanger 2000; Mikdad et al. 2002) suggests population continuity without replacement as the likely scenario.

\section{Kef Zoura D, a case study in continuity}

The KZD rockshelter is the only site at which modern techniques of excavation and analysis have been used and in which there is clear evidence for both varieties of Capsian. It spans most of the period during which the Capsian flourished in eastern Algeria, and contains at least five separate stratigraphic units, identified on the basis of visible stratigraphy and variability in both land snail and lithic assemblages. Units I-III are Upper Capsian. The limited sample from Unit IV is a variety of Typical Capsian, differing slightly from the much larger sample of Typical Capsian in Unit V, the earliest dated deposit. Units I-IV were exposed in the Main Trench beneath the shelter overhang, while Unit V was exposed only in the T20-5 test pit excavated in

\footnotetext{
${ }^{1}$ Uncalibrated dates are given in years BP using the Libby half-life when \pm values are shown. Calibrated dates (see Table 1) use CALIB 5.0.1 (Reimer et al. 2004, Stuiver and Reimer 1993) and are designated as calBP.
} 
the talus slope in front of the shelter (Fig. 2). The undated lithic assemblage from T20-10 has not yet been studied in detail but preliminary work suggests it was at least partly in situ and is also Typical Capsian. Given the excellent preservation of stratigraphy within the shelter, the fact that bedrock has not yet been reached, and the presence of Levallois technology artefacts on the surface in the vicinity, there is a possibility that pre-Capsian deposits might be found at KZD if investigations could be continued.
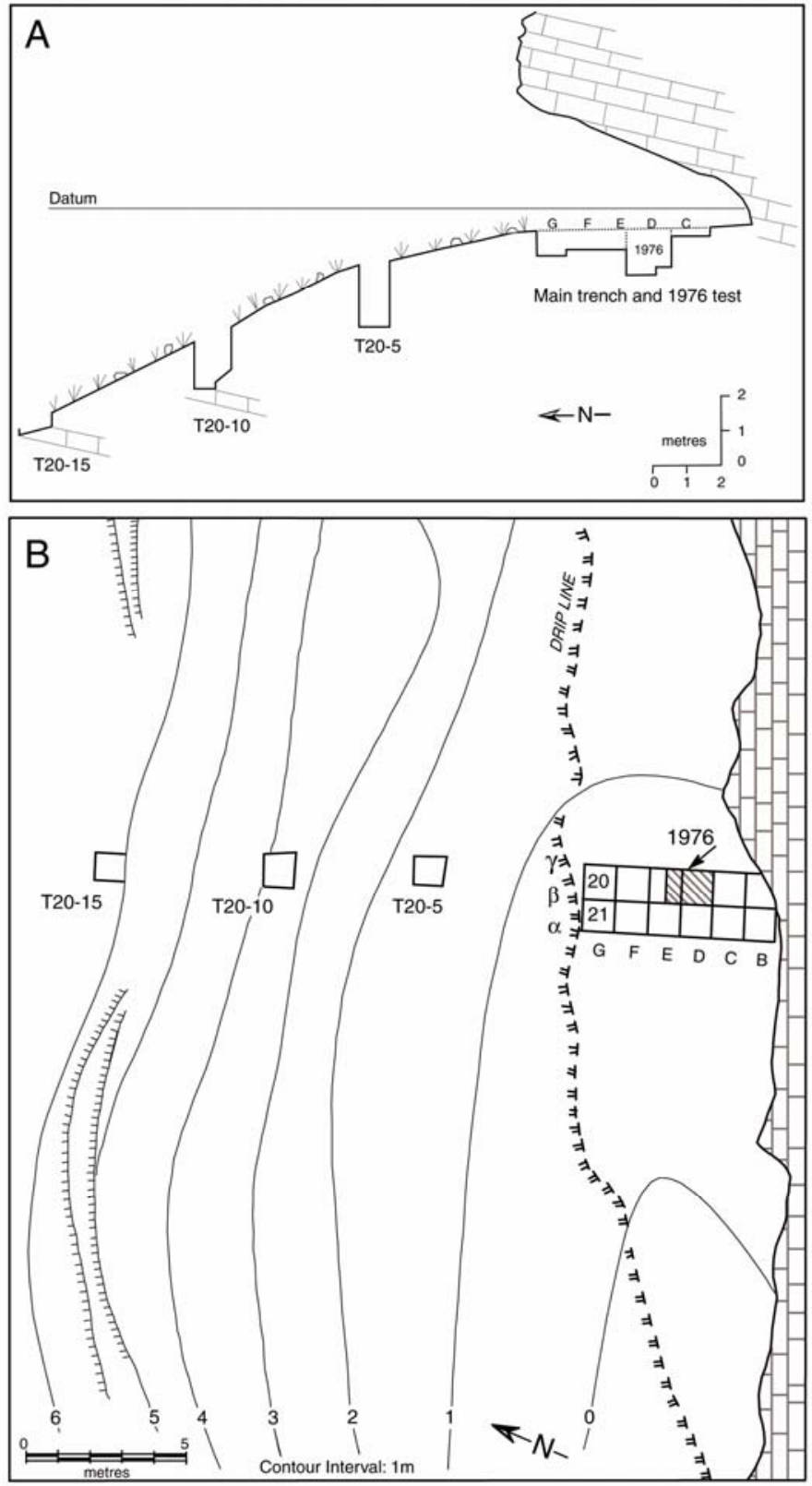

Figure 2 Kef Zoura D cross-section (A) and plan view (B) showing location of excavations and tests. 


\section{Chronology}

Nineteen radiocarbon dates are available for KZD (Table 1 and Fig. 3). Two of the samples were land snail shell and the remainder charcoal.

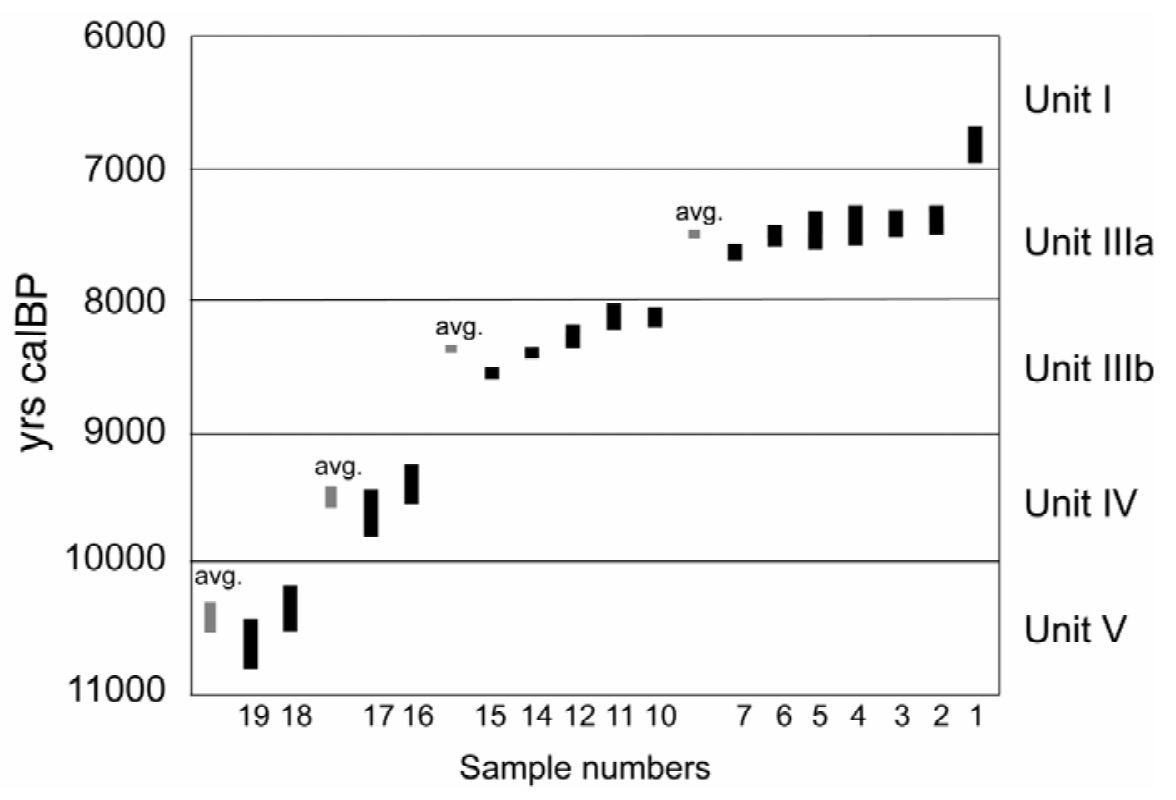

Figure 3 Kef Zoura D radiocarbon dates. Black bars are $1 \sigma$ ranges for individual dates, grey bars are $1 \sigma$ ranges for weighted means. Calibrations done with CALIB 5.0.1 (Reimer et al. 2004, Stuiver and Reimer 1993). See Table 1 for sample details.

At least $50 \mathrm{~cm}$ was removed from the top of the KZD deposits sometime in the past. Thus the modern surface truncates the top of Unit I, which is dated by a single radiocarbon sample (KZD 1) to about $6800 \mathrm{calBP}$. Unit II is undated because no charcoal was present. Unit IIIa is dated by six samples (KZD 2 to 7 ) to about 7500 calBP and appears to represent a single event because there is no statistically significant difference among the samples. Unit IIIb is dated by eight samples (KZD 8 to 15) but samples 8, 9 and 13 are considered unreliable due to high error resulting from small sample size and are not used in computing the weighted mean for this unit of about 8360 calBP. Unit IV is dated by two samples (KZD 16 and 17) to about 9500 calBP and represents a Typical Capsian assemblage. Unit V, also containing a Typical Capsian assemblage, is dated by two samples (KZD 18 and 19) to at least 10,400 calBP. 


\begin{tabular}{|c|c|c|c|c|c|c|c|}
\hline Unit & ID & Lab. Number & $\begin{array}{c}\text { Provenance } \\
\text { (cm below datum) }\end{array}$ & $\begin{array}{c}\text { Material } \\
\& \text { weight }(\mathrm{g})\end{array}$ & $\mathrm{T}^{1} 1 / 2=5568$ & $\begin{array}{l}1 \sigma \text { range } \\
\text { calBP }\end{array}$ & $\begin{array}{l}2 \sigma \text { range } \\
\text { calBP }\end{array}$ \\
\hline I & KZD 1 & I-9835 & 1976: $90-95$ & Charcoal (nd) & $5965 \pm 115$ & $6664-6947$ & $6533-7032$ \\
\hline IIIa & KZD 2 & I-9836 & 1976: $125-130$ & Charcoal (nd) & $6485 \pm 125$ & $7272-7494$ & $7162-7607$ \\
\hline IIIa & KZD 3 & I-9837 & 1976: $145-150$ & Charcoal (nd) & $6505 \pm 125$ & $7295-7558$ & $7170-7607$ \\
\hline IIIa & KZD 4 & SMU-1099 & E20D: 120 & Charcoal (0.5) & $6520 \pm 170$ & $7274-7569$ & $7145-7691$ \\
\hline IIIa & KZD 5 & I-9838 & 1976: $165-170$ & $\begin{array}{c}\text { Charcoal } \\
\text { ("undersized") }\end{array}$ & $6575 \pm 170$ & $7316-7607$ & $7156-7794$ \\
\hline IIIa & KZD 6 & SMU-1084 & F20D: 114-118.5 & Charcoal (0.9) & $6620 \pm 110$ & $7427-7586$ & $7316-7675$ \\
\hline IIIa & KZD 7 & SMU-1154 & E20D: 133 & Charcoal (2.4) & $6770 \pm 90$ & $7519-7690$ & $7465-7793$ \\
\hline \multicolumn{5}{|c|}{ weighted mean of KZD 2, 3, 4, 5, 6, 7} & $6612 \pm 51$ & $7462-7564$ & $7432-7572$ \\
\hline $\mathrm{IIIb}$ & KZD 8 & SMU-1081 & E20D: 135 & Charcoal $(0.5)$ & $7150 \pm 200$ & $7764-8178$ & $7621-8354$ \\
\hline $\mathrm{IIIb}$ & KZD 9 & SMU-1096 & F20A: 123 & Charcoal (0.2) & $7210 \pm 340$ & $7713-8352$ & $7421-8775$ \\
\hline IIIb & KZD 10 & SMU-1120 & G21A: $85-88$ & Charcoal (2.4) & $7350 \pm 50$ & $8048-8279$ & $8027-8223$ \\
\hline $\mathrm{IIIb}$ & KZD 11 & AECV-1812C & F21D: $80-86$ & Charcoal (3.3) & $7340 \pm 120$ & $8022-8303$ & $7956-8380$ \\
\hline $\mathrm{IIIb}$ & KZD 12 & AECV-1813C & F21C: 99-111 & Charcoal (8.0) & $7430 \pm 90$ & $8176-8351$ & $8042-8392$ \\
\hline $\mathrm{IIIb}$ & KZD 13 & SMU-1097 & F20B: 109.5 & Charcoal $(0.3)$ & $7442 \pm 560$ & $7704-8975$ & $7230-9547$ \\
\hline $\mathrm{IIIb}$ & KZD 14 & SMU-1095 & G20C: $110-122$ & Charcoal (2.5) & $7590 \pm 60$ & $8346-8441$ & $8306-8541$ \\
\hline $\mathrm{IIIb}$ & KZD 15 & SMU-1082 & F20B: $82-104$ & Snail shell (2.4) & $7750 \pm 50$ & $8458-8587$ & $8420-8603$ \\
\hline \multicolumn{5}{|c|}{ weighted mean of KZD 10, 11, 12, 14, 15} & $7536 \pm 28$ & $8349-8384$ & $8324-8405$ \\
\hline IV & KZD 16 & SMU-1121 & G20C: 138 & Charcoal (0.8) & $8390 \pm 170$ & $9137-9536$ & $8977-9782$ \\
\hline IV & KZD 17 & SMU-704 & T20-5: 250 & Charcoal (1.0) & $8580 \pm 150$ & $9427-9885$ & $9264-9964$ \\
\hline \multicolumn{5}{|c|}{ weighted mean of KZD 16 \& 17} & $8497 \pm 114$ & $9311-9584$ & $9197-9741$ \\
\hline $\mathrm{V}$ & KZD 18 & SMU-1108 & T20-5: $270-280$ & Snail shell (1.2) & $9100 \pm 130$ & $10157-10500$ & $9887-10592$ \\
\hline $\mathrm{V}$ & KZD 19 & SMU-712 & T20-5: $270-280$ & Charcoal (0.9) & $9390 \pm 130$ & $10407-11061$ & $10258-10894$ \\
\hline \multicolumn{5}{|c|}{ weighted mean of KZD 18 \& 19} & $9244 \pm 93$ & $10278-10513$ & $10233-10606$ \\
\hline
\end{tabular}

Table 1 Kef Zoura D radiocarbon dates. Calibration using CALIB 5.0.1 and intcal04.14c (Reimer et al. 2004). One sigma $(1 \sigma)$ ranges are used for calculation of dates discussed in text and shown in Figure 4 where complex stratigraphy requires tight chronological control. 
Stratigraphy as shown by variability in land snail, vertebrate and lithic assemblages

The stratigraphy of KZD is shown in Fig. 4, with the relationship of Units I-IV indicated in Fig. $4 \gamma$. The 1976 test (Fig. $4, \beta$ left profile) was excavated in arbitrary $5 \mathrm{~cm}$ spits and seemed to show rather simple stratigraphy, including the burial of a sub-adult beneath a cairn of rocks. The dates (KZD 1, 2, 3, 5) indicated rapid deposition ca. 7500-7400 calBP, perhaps a single event.

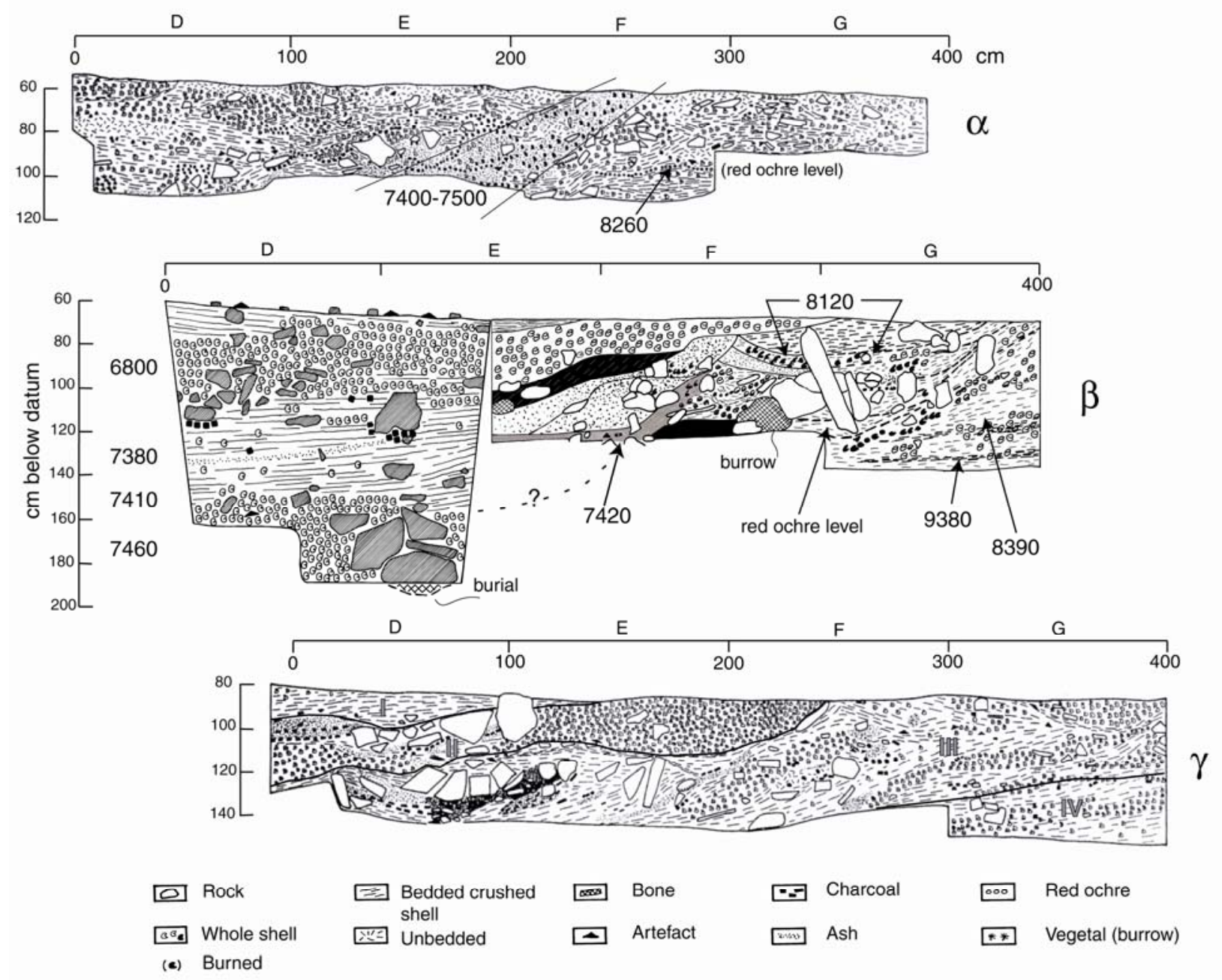

Figure 4 Kef Zoura D main trench sections: $\alpha$, west face; $\beta, 1976$ test (left) and reconstructed centre line (right) showing stratigraphy between the 20 and 21 lines; $\gamma$, east face with limits of Units I to IV indicated.

In $\beta$ (right profile), the dark grey deposits are compacted pink-brown ash and burnt limestone. The lower black deposit is extremely hard and sterile while the upper black deposit (with hachures), which everywhere underlies the snail pit, is also sterile but loose. The red ochre level is compacted, brown and rich in artefacts. The radiocarbon dates shown are rounded calibrated $1 \sigma$ values derived from the mid-point of the range of probability: those for the 1976 test ( $\beta$ left profile) refer to $5 \mathrm{~cm}$ levels while 
those for the Main Trench ( $\beta$ right profile) are plotted to precise locations.

The $\alpha$ and $\gamma$ profiles were drawn in the field at the close of the 1978 season by DL

with assistance from MJ and Peter Sheppard respectively. The 1976 test ( $\beta$ left profile) was drawn in the field by Achilles Gautier with assistance from DL. The reconstructed centre line ( $\beta$ right profile) is the work of MJ. For location of these profiles see Fig. 2.

The more detailed excavations in 1978 followed observable stratigraphy and revealed a complex series of sharply sloping and horizontal levels (Fig. $4, \beta$ right profile). Most of the deposits (those in squares $\mathrm{F}$ and $\mathrm{G}$ ) were at least 600 years older than those in the 1976 test.

Analysis of the land snail samples was the key to interpreting the stratigraphy. Following the procedures used at AM (Lubell et al. 1976), samples were taken systematically every $5 \mathrm{~cm}$ in the 1976 test, but this was modified in 1978 so that samples represented changes observed during excavation of the sloping and complex deposits. Hierarchical cluster analysis of these samples (Fig. 5) demonstrates that representation of snail genera changed through time. At the very top, under the shelter rear wall, Unit I is marked by a high frequency of Otala sp. Below that, there is a pit with extremely high levels of Helix melanostoma that we call Unit II and which is visible in the profiles of the centre line and east face of the main trench (Fig. 4, $\beta$ and $\gamma$ ). Below and beyond the shell pit is Unit III, in which the smaller Helicella sitifensis and Leucochroa candissima dominate. It contains several elements, some sloping sharply. At the drip line, Unit III is underlain by older and less sloping levels, which we call Unit IV. Related to this, but in a manner we were unable to determine during the excavation, are the similar deposits exposed in T20-5, that we call Unit V, in which Helix melanostoma again predominates.

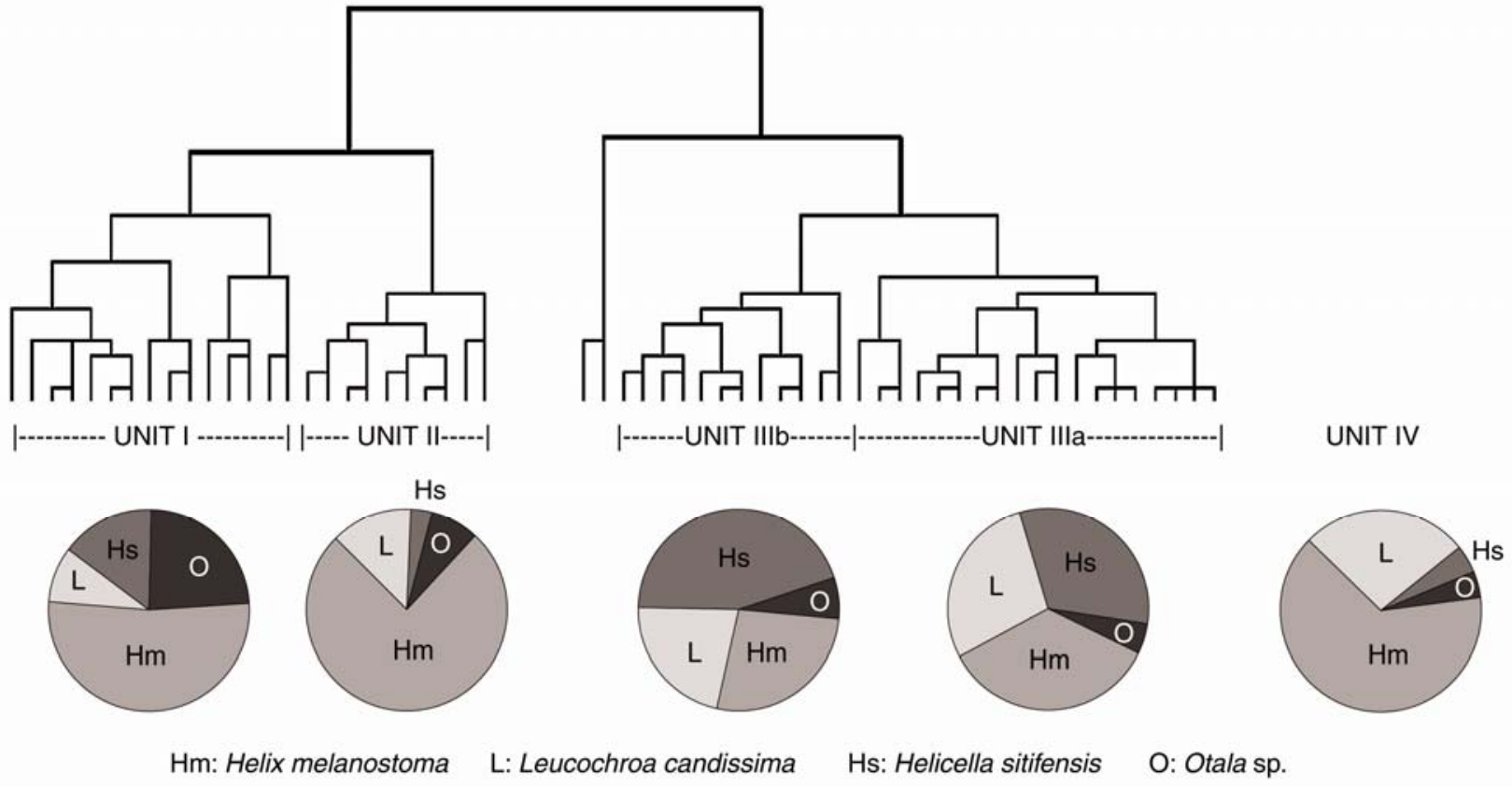

Figure 5 Hierarchical cluster analysis of snail samples $(n=18,294$ shells $)$ from the Kef Zoura D main trench excavations using complete linkage and the phi square distance measure. Note that two samples are excluded from further analysis because of anomalously high frequencies of Helicella sitifensis (see discussion in text). 
The Unit III samples include variations, all basically on the same theme but identifiable to various elements. The Unit IIIb subcluster (Fig. 5) includes samples with high frequencies of $H$. sitifensis from two periods: some were associated with a red ochre level dated to around 8200 calBP, but others occur in younger levels immediately overlying the burial. The rapid filling of the burial pit probably explains their occurrence, a result of older material having been thrown on top of the burial cairn and shell pile. There are two anomalous snail samples in Unit III in which the mean frequency of $H$. sitifensis was $70 \%$ (Fig. 5). We exclude these from the analysis here so as not to overstate our case. Nonetheless, it is clear that Unit III samples, as a whole, contain many $H$. sitifensis shells.

$H$. sitifensis (as well as L. candissima) both reach high frequencies today in the semi-arid environment around KZD, whereas H. melanostoma is less common because it prefers more humid habitats and greater shade (Lubell et al. 1975: 71-75). Therefore, the juxtaposition of high frequencies of $H$. melanostoma in Units II and IV and the abundance of $H$. sitifensis in Unit III have environmental implications. We conclude that during the Unit III occupation, the surrounding environment was at least semi-arid in contrast to the conditions that prevailed earlier (Unit IV) and later (Unit II).

It is worth re-emphasizing the complexity of the situation at KZD, where adjacent deposits may be of markedly different time periods. The west wall of the main trench (Fig. $4 \alpha$ ) shows how levels can first slope down from south to north and then sharply up from south to north, be disrupted by pits, or be relatively horizontal. Adjacent deposits may be hundreds of years apart in age. In the west wall (Fig. $4 \alpha$ ) a deposit of pink ash which slopes up from the test pit, where it is dated 7400-7500 calBP (KZD 1,3 and 5), abuts a well defined red ochre level dated to 8260 calBP (KZD 12).

As well as the snail samples, there are the mammal bones. We have smaller samples of bone in the main trench than from T20-5 and T20-10 outside the drip line, and the activities within the rock shelter with regard to butchering of animals were likely to have been quite specialized. This is highlighted by comparing Units IV and V (Fig. 6), which we believe to be partly contemporaneous. 


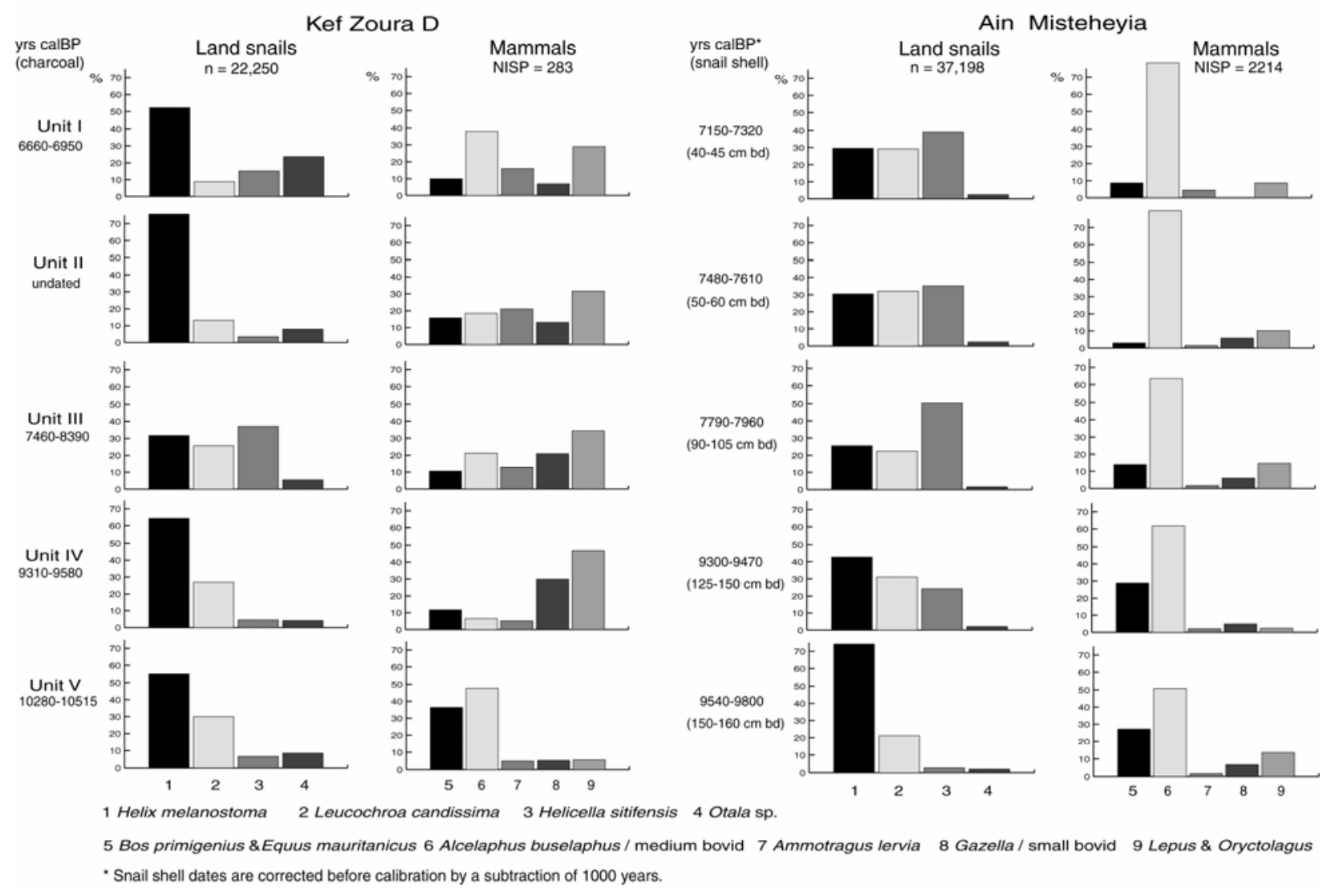

Figure 6 Aïn Misteheyia and Kef Zoura D faunal assemblages.

Radiocarbon dates for Aïn Misteheyia are all on land snail shell and were corrected prior to calibration by subtracting 1000 years to compensate for incorporation of dead carbon (Evin et al. 1980; Goodfriend 1987).

Unit IV represents an area within the shelter where lagomorph-sized mammals were processed and/or eaten and where a great deal of pistachio wood was burnt. Unit V, outside the shelter, appears to be an area in which hartebeest and/or bos-sized animals were butchered and pistachio, cedar and juniper were burnt (unpublished analyses by A.C. D'Andrea and C.T. Shay: D'Andrea et al. 1995). Despite the fact that Unit V deposits would have been more exposed to weathering, we cannot ascribe the differences entirely to non-cultural causes. As with the variability in land snail assemblages, the differences in vertebrate species suggest environmental changes with earlier moister conditions and later more arid ones.

The small lithic assemblage from Unit IV is similar to, but not identical with, the much larger one from Unit V. Changes in blank production and frequencies of burins and backed bladelets suggest that Unit IV lithics have characteristics of both Typical and Upper Capsian (Sheppard 1988). Unfortunately, we cannot be more specific because of the small size of the Unit IV 
assemblage. The KZD sequence documents the introduction of the pressure technique sometime during the formation of Unit IV. Data from other sites demonstrate that this development can also be observed in purely Upper Capsian sequences such as Medjez II (Camps-Fabrer 1975; Sheppard 1987; Rahmani 2004b). The presence of a method for producing bladelets which are very standardized in their dimensions appears to have had an important effect on form and frequency of geometrics and backed bladelets. However, at KZD there is some evidence from Unit IV to suggest that the change from Typical to Upper Capsian occurred after the introduction of this new technique. It therefore seems probable that there is a relationship between the increased use of the new technique and the end of the Typical Capsian.

Our excavations in Square G20, at the shelter drip line, ended just at the point where changes in the artifact assemblage were showing up in Unit IV. The Unit V assemblage from T20-5 is indisputably Typical Capsian but has not yet been fully studied. The Unit IV assemblage from G20 is also Typical Capsian but perhaps not identical to the one in T20-5. The Unit IV and V assemblages span a period from ca. 10,500 to 9300 calBP (KZD 16-19). Unfortunately, we did not have time to explore the relationship of the deposits in T20-5 to those in G20 during the 1978 excavations. Field work has not been possible since then.

\section{Comparison with Relilaï}

Relilaï, a large rockshelter just to the north of KZD (Fig. 1), was used by Vaufrey (1936) to define the Capsian sequence. Grébénart (1976) re-excavated here, exposing deposits containing both Typical and Upper Capsian which he interpreted to be contemporaneous on the basis of radiocarbon dates. Given the excavation methods he used and the lack of precise provenance for his radiocarbon samples, we suggest that his interpretation of contemporaneity for Typical and Upper Capsian at Relilaï may be incorrect. It seems very likely that all the older dates at Relilaï are for Typical Capsian deposits. Grébénart attributes one rather early date (Gif 1900, $7800 \pm 140 ; 8770-8600$ calBP) to the Upper Capsian, but this is based on his method of analyzing the lithic assemblages within each $10 \mathrm{~cm}$ spit of a $0.5 \mathrm{~m}^{2}$ excavation unit. The other Upper Capsian date (Gif 1899, 7300 $\pm 140 ; 7980-8100$ calBP) is much later. Two dates, definitely associated with Typical Capsian are Gif $2119(7700 \pm 150 ; 8650-8580 \mathrm{calBP})$ and Gif 1714 $(7760 \pm 180 ; 8780-8580$ calBP), the latter from deposits near the drip line.

Grébénart rejected these four dates because they were not sequential. However, we suggest they are in accord with the east-west slope of the deposits that Lubell and Gautier observed in 1972 in the south face of Grébénart's LMN trench, a situation similar to that which we later found at KZD. Furthermore, the east profile at KZD (Fig. $4 \gamma$ ), shows the same sort of surface pits and sloping levels and lenses of shells as at Relilaï. Apart from Gif 1900, the chronological separation of Typical and Upper Capsian at Relilaï fits precisely with what we see at KZD. The published details on the trench (D31 to 33) and on the deposits relevant to the suspect date, specified only as sloping and directly adjacent to Typical Capsian material, are minimal (Grébénart 1976: 143-147). One needs a provenance for the dated charcoal more precise than to $20 \%$ of $1.0 \mathrm{~m}^{3}$, just as for the proper interpretation of the LMN dates which represent up to $30 \%$ of $1.0 \mathrm{~m}^{3}$ of deposit. 


\section{Comparison with Aïn Misteheyia}

Aïn Misteheyia (AM) was excavated in 1973 and 1976 (Lubell et al. 1975, 1976, 1982-83). It was an open-air escargotière, listed by Grébénart (1976: 51-52) as Aïn Messaïa or site 36. Visible stratigraphy proved difficult to follow due to deflation and compaction of the deposits (Lubell et al.1982-83, especially Fig. 2), even though we were able to identify one occupation surface (Lubell et al. 1975: Fig. 20) at $\sim 40-50 \mathrm{~cm}$ below datum. Unfortunately the site was completely destroyed by deep ploughing for re-forestation sometime between 1976 and 1978 .

The vertebrate faunal assemblage at AM shows a pattern similar to KZD, with greater numbers of larger species in the earlier deposits, but the pattern is more uniform with a predominance of hartebeest (Alcelaphus buselaphus) throughout (Fig. 6). Comparison of the land snail assemblages is complicated by KZD Unit II which consists almost entirely of Helix melanostoma shell. In earlier levels, both sites follow a similar trend. The land snail data for AM 125-150 and 150-160 combined $(\mathrm{n}=6052)$ and KZD Unit IV $(\mathrm{n}=1346)-$ Helix, 61.8\% vs 54.5\%;

Leucochroa, 27\% vs 27\%; Helicella, 9\% vs 14\%; Otala, 2\% vs 4\% - are significantly different. This might be expected because the different site settings would have meant distinctive local land snail populations (see Lubell et al. 1975: 71-75). However, each site shows a similar change through time: in general terms, the pattern first observed at AM, with larger, more shade and moisture adapted species earlier in the sequence and more arid adapted species later, appears consistent. Unit II at KZD is a unique, probably single-event, assemblage while Unit I is likely to be biased due to post-depositional disturbance. It is difficult to be more precise because our sampling procedures were different during the two excavations: at AM, 1 litre bulk samples were collected from every $5 \mathrm{~cm}$ spit in every $1 \mathrm{~m}^{2}$ excavation unit, whereas at KZD we collected such samples from visible features and/or stratigraphic units.

Using radiocarbon dates on land snail shell and analyses of the granulometry, geochemistry, archaeozoology and archaeology of the deposits, we divided the site into upper and lower levels defined as follows (Lubell et al. 1982-83: 69):

Upper levels: From surface to about $65 \mathrm{~cm}$; high frequencies of shell with Helicella sitifensis most abundant; less bone with smaller mammals (especially lagomorphs); small tools and debitage; blades twice as numerous as flakes; major retouched tool groups are notches and denticulates (31\%), backed bladelets (24\%), geometric microliths ( $8 \%)$; approximate dates of 7700 to at least $7300 \mathrm{BP}$.

Lower levels: From about $65 \mathrm{~cm}$ to sterile substrate at between 150 and $175 \mathrm{~cm}$; low frequencies of shell with Helix melanostoma most abundant; more abundant bone with a predominance of larger mammals (Alcelaphus, Bos, Equus); large tools and debitage; equivalent frequencies of flakes and blades; major retouched tool groups are backed bladelets $(33 \%)$, notched and denticulated $(15 \%)$, burins $(13.5 \%)$; approximate dates of 9800 to $7700 \mathrm{BP}$. 
Sheppard $(1987,1988)$ could not confirm a Typical Capsian-Upper Capsian sequence here, but Rahmani (2003, 2004a, 2004b), using a different methodology and a larger comparative sample, finds evidence for both varieties at AM.

These significant changes at AM therefore occurred at approximately $7700 \mathrm{BP}$ or ca. 8500 calBP. However, since all the AM radiocarbon samples were land snail shell, processed before AMS was available and using methods now considered less than ideal, the true calibrated age may be between 300 and 500 years younger. In any case, the situation is remarkably similar to KZD, where Typical Capsian occurs prior to $8400 \mathrm{calBP}$ and Upper Capsian after 8300 calBP.

\section{Archaeological stratigraphy and regional Holocene palaeoenvironments}

The period of the KZD Unit III deposits was one of change. We propose that during Unit III conditions became increasingly arid. We cannot date the beginning of this trend but it had begun by 8400 calBP. Unit III has a preponderance of smaller arid-adapted snails in comparison with earlier and later units, and this is particularly noteworthy in samples dated around $8200 \mathrm{cal} \mathrm{BP}$ (Fig. 6).

We excavated nearly a cubic metre of deposit recognized as Unit II: in some areas over $40 \%$ of the deposit consisted of complete Helix melanostoma shells. We interpret this as a single event or a rapid series of short-term events. We envisage a very damp winter in which people could collect hundreds of Helix in a single day.

Thus we have a remarkable change from Unit III: Unit II shell samples may contain up to $80 \%$ Helix, but in Unit III there are anomalous samples of nearly $80 \%$ Helicella - a clear indication of greater aridity

To what might this development be related? At both AM and KZD there are contemporaneous changes in both the faunal and lithic assemblages. At AM this occurs at about $95 \mathrm{~cm}$ below datum, while at KZD it is one of the characteristics which distinguishes the deposits in the main trench from those in T20-5. The earlier levels at both sites contain a greater proportion of larger mammals (Bos, Alcelaphus, Equus), while the later levels are characterized by smaller, more arid-adapted species (Gazella, lagomorphs). At the same time, especially at AM, there is a change in the frequency of land snail species from predominance of the larger Helix melanostoma to smaller species such as Helicella setifensis and Leucochroa candissima which are better adapted to more arid conditions.

These changes are penecontemporaneous with the 8200 calBP event (Alley et al. 1997), also called the Abrupt Early to Mid-Holocene Climatic Transition or EMHT (Stager and Mayewski 1997). We had actually observed this previously at AM but did not identify it as such (Lubell et al. 1975, 1976) and that interpretation is now confirmed by isotopic analysis of the snail shells from the AM deposits and from live snails collected in the environs in 1973 (Faber et al. 2007) as well as at KZD (Lubell et al. 2008). 
Limnological and palynological analyses at Lake Tigalmamine in the Moroccan Atlas (Lamb et al. 1989, 1995; Lamb and van der Kaars 1995) show that a long period of aridity was initiated after 9200calBP. It is not possible to identify the EMHT because the two analyzed cores are not dated to the specific period: nevertheless a decrease in the percentage of Quercus canariensis in core C86 at what must be ca. 8200 calBP (Lamb et al. 1995, Fig. 1 at ca. $28.7 \mathrm{~m}$ ) may indicate stress on a species which is not drought tolerant (perhaps associated with increased run-off). While it is generally agreed that aridity increased after 9000 calBP in North Africa, latitudinal and altitudinal diversity in the Maghreb and elsewhere resulted in varied conditions during the Holocene (e.g., Claussen et al. 2003, COHMAP 1998, Combourieu Nebout et al. 2002, Couvert 1972, Damnati 2000, deMenocal et al. 2000, Hassan 1997, Street-Perrott and Perrott 1993, Vernet 1995; Wengler and Vernet 1992, Zielhofer et al. 2004).

\section{Conclusion}

Radiocarbon analyses and changes in faunal and lithic assemblages at Kef Zoura D and Aïn Misteheyia demonstrate a close relationship between environmental and cultural changes centred around the 8200 calBP event or EMHT. Earlier deposits at both sites are characterized by larger invertebrate and vertebrate fauna indicative of wetter conditions associated with lithic assemblages that can be described as Typical Capsian. Later deposits contain smaller fauna indicative of increased aridity and lithics characteristic of the Upper Capsian. Our data lead us to conclude that contemporaniety of Typical and Upper Capsian hypothesized for neighbouring sites and further afield cannot be substantiated. Instead, there is evidence for a succession from earlier Typical to later Upper, as proposed by Vaufrey 70 years ago. At both KZD and AM we see evidence for a transitional phase in lithics, the trend intensifying around the time of the EMHT. There is thus very clear evidence at KZD and AM for continuity between the Typical and Upper Capsian, as appears to be the case throughout the Maghreb.

\section{Acknowledgments}

This paper is the result of many years of research, supported by grants to DL from the WennerGren Foundation for Anthropological Research (1972), the Canada Council (1973-74), the Social Sciences and Humanities Research Council of Canada (1974-82), and the University of Alberta (1994-98). Our colleagues William Farrand, Achilles Gautier, Fekri Hassan, James Ritchie and Peter Sheppard have contributed much to the development of the ideas expressed here. 


\section{References}

Alley, R.B., Mayewski, P.A., Sowers, T., Stuiver, M.., Taylor, K.C., and Clark, P.U. (1997) Holocene climatic instability: a prominent, widespread event 8200 yr ago. Geology, 25(6): 483-486.

Barton, R.N.E., Bouzouggar, A., Humphrey, L.T., Berridge, P., Collcutt, S.N., Gale, R., Parfitt, S., Parker, A.G., Rhodes, E.J., Schwenninger, J.L. (2008) Human burial evidence from Hattab II Cave (Oued Laou-Tétuoan, Morocco) and the question of continuity in Late Pleistocene-Holocene mortuary practices in Northwest Africa. Cambridge Archaeological Journal (In press).

Camps, G. (1968) Le Capsien supérieur: état de la question. In Bordes, F. and de Sonneville-Bordes, D. (eds.), La Préhistoire: Problèmes et Tendances. Centre National de la Recherche Scientifique, Paris, pp. 87-101.

Camps, G. (1974) Les Civilisations Préhistoriques de l'Afrique du Nord et du Sahara. Doin, Paris.

Camps, G. (1975) The prehistoric cultures of North Africa: radiocarbon chronology. In Wendorf, F. and Marks, A.E. (eds.), Problems in Prehistory: North Africa and the Levant, Southern Methodist University Press, Dallas, pp.181-192.

Camps, G., Delibrias, G. and Thommeret, J. (1968) Chronologie absolue et succession des civilisations préhistoriques dans le Nord de l'Afrique. Libyca (16: 9-28.

Camps-Fabrer, H. (1975) Un Gisement Capsien de Faciès Sétifien: Medjez II, El-Eulma (Algérie). Éditions du CNRS, Paris.

Claussen, M., Brovkin, V., Ganopolski, A., Kubatzki, C. and Petoukhov, V. (2003) Climate change in northern Africa: the past is not the future. Climatic Change 57: 99-118.

Close, A. (1980) Current research and recent radiocarbon dates from northern Africa. Journal of African History, 21: $145-167$.

Close, A. (1984) Current research and recent radiocarbon dates from northern Africa, II. Journal of African History, 25:1-24.

Close, A. (1988) Current research and recent radiocarbon dates from northern Africa, III. Journal of African History, 29:145-176.

Close, A.E., and Wendorf, F. (1989) North Africa at 18000 BP. In Gamble, C. and Soffer, O. (eds.), The World at 18000 BP. Volume 2. Low Latitudes, Unwin Hyman, London, pp. 41-56.

COHMAP Members (1988) Climatic changes of the last 18,000 years: observations and model simulations. Science 241: 1043-1052.

Combourieu Nebout, N., Turon, J.L., Zahn, R.,Capotondi, L., Londeix, L. and Pahnke, K. (2002) Enhanced aridity and atmospheric high-pressure stability over the western Mediterranean during the North Atlantic cold events of the past 50 k.y. Geology 30 (10): 863-866.

Couvert, M. (1972) Variations paléoclimatiques en Algérie: traduction climatiques des informations paléobotaniques fournies par les charbons des gisements préhistoriques. Note préliminaire. Libyca 20: 45-48. 
Damnati, B. (2000) Holocene lake records in the northern hemisphere of Africa. Journal of African Earth Sciences 31: $253-262$.

D'Andrea, A.C., Shay, C.T. and Lubell, D. (1995) Wood charcoal and palaeoecological reconstructions: an example from Kef Zoura D, Algeria. 28th Annual Mtg., Canadian Archaeological Association. Kelowna, May 1995.

deMenocal, P., Ortiz, J., Guilderson, T., Adkins, J., Sarnthein, M., Baker, L. and Yarusinsky, M. (2000) Abrupt onset and termination of the African Humid Period: rapid climate responses to gradual insolation forcing.

Quaternary Science Reviews 19: 347-361.

Evin, J., Marechal, J., Pachiaudi, C. and Puissegur, J.J. (1980) Conditions involved in dating terrestrial shells. Radiocarbon 22: 545-555.

Faber, M.L., Yapp, C.J. and Lubell, D. (2007) Stable isotope composition of land snails from an $~ 8 \mathrm{ka}$ B.P. archaeological site in eastern Algeria. Paper presented at session on Sourcing Techniques in Archaeology, Geological Society of America Annual Meeting, Denver 28-31 October 2007.

Goodfriend, G.A. (1987) Radiocarbon age anomalies in shell carbonate of land snails from semi-arid areas. Radiocarbon 29: 159-167.

Grébénart, D. (1976) Le Capsien des Régions de Tébessa et d'Ouled-Djellal, Algérie: contribution à son étude. Études méditerranéennes 1, Éditions de l’Université de Provence, Aix-en-Provence.

Groves, C. and Thorne, A. (1999) The terminal Pleistocene and early Holocene populations of Northern Africa. Homo 50: 249-262.

Hachi, S. (1996) L'Ibéromaurusian, découverte des fouilles d'Afalou (Bédjaîa, Algérie). L'Anthropologie 100: 5576.

Hachi, S. (1997) Résultats des fouilles récentes d'Afalou Bou Rmel (Bédjaîa, Algérie). In Fullola, J.M and Soler, N. (eds.), El Món Mediterrani Despres del Pleniglacial (18.000-12.000 BP), Museu d'Arqueologia de Catalunya, Girona, pp. 77-92.

Hassan, F.A. (1997) Holocene palaeoclimates of Africa. African Archaeological Review 14: 213-230.

Irish, J.D. (2000) The Iberomaurusian enigma: North African progenitor or dead end? Journal of Human Evolution, 39: 393-410.

Klein, R.G. and Scott, K. (1986) Re-analysis of faunal assemblages from the Haua Fteah and other Late Quaternary archaeological sites in Cyrenaïcan Libya. Journal of Archaeological Science 13: 515-542

Lamb, H.F., Eicher, U. and Switsur, V.R. (1989) An 18,000-year record of vegetation, lake-level and climatic change from Tigalmamine, Middle Atlas, Morocco. Journal of Biogeography 16: 65-74.

Lamb, H.F., Gasse, F., Benkaddour, A., El Hamouti, N., van der Kaars, S., Perkins, W.T., Pearce, N.J. and Roberts, C.N. (1995) Relation between century-scale Holocene arid intervals in tropical and temperate zones. Nature 373: 134-137.

Lamb, H.F. and van der Kaars, S. (1995) Vegetational response to Holocene climatic change: pollen and palaeolimnological data from the Middle Atlas, Morocco. The Holocene 5: 400-408. 
Lubell, D. (1984) Paleoenvironments and epipaleolithic economies in the Maghreb (ca. 20,000 to 5,000 B.P.). In Clark, J. D. and Brandt, S. (eds.), From Hunters to Farmers: Considerations of the Causes and Consequences of Food Production in Africa,University of California, Berkeley, pp. 41-56.

Lubell, D., Ballais, J-L., Gautier, A. and Hassan, F.A. (1975) Prehistoric cultural ecology of Capsian escargotières: preliminary results of an interdisciplinary investigation in the Chéria-Télidjène region. Libyca 23: 43-121.

Lubell, D., Hassan, F.A., Gautier, A. and Ballais, J-L. (1976) The Capsian escargotières. Science 191: 910-920.

Lubell, D., Gautier, A., Leventhal, E.T., Thompson, M.., Schwarcz H.P. and Skinner, M. (1982-83) Prehistoric cultural ecology of Capsian escargotières, Part II: report on investigations conducted during 1976 in the Bahiret Télidjène, Tebessa Wilaya, Algeria. Libyca 32-33: 59-142.

Lubell, D., Sheppard, P. and Jackes, M. (1984) Continuity in the Epipaleolithic of Northern Africa with emphasis on the Maghreb. In Wendorf, F. and Close, A.E. (eds.), Advances in World Archaeology, 3, Academic Press, New York, pp. 143-191.

Lubell, D., Sheppard, P. and Gilman, A. (1991) The Maghreb. In Ehrich, R.W. (ed.), Chronologies in Old World Archaeology, 3rd Edition,: University of Chicago Press, Chicago, I: pp. 305-308 and II: pp. 257-267.

Lubell, D., Jackes, M., Faber, M. \& Yapp, C. (2008). Land snail stable isotopes and the Capsien typique-Capsien supérieur transition in eastern Algeria. Paper presented at the ICAZ 2nd Archaeomalacology Working Group Meeting Santander, February 2008.

Mikdad, A. and Eiwanger, J. (2000) Recherches préhistoriques dans le Rif oriental (Maroc) : rapport préliminaire. Beiträge zur Allegemeinen und Vergleichenden Archäologie 20: 109-167.

Mikdad, A., Moser, J. and Ben-Ncer, A. (2002) Recherches préhistoriques dans le gisement d'Ifri n'Ammar au Rif oriental (Maroc). Beiträge zur Allegemeinen und Vergleichenden Archäologie 22: 1-20.

Rahmani, N. (2003) Le Capsien Typique et Le Capsien Superieur; Evolution Ou Contemporaneite. Les Donnees Technologiques. Cambridge Monographs in African Archaeology No. 57. BAR International Series 1187.

Rahmani N. (2004a) Nouvelle interprétation de la chronologie Capsienne. Bulletin de la Société Préhistorique Française 101(2): 345-360.

Rahmani N. (2004b) Technological and cultural change among the last hunter-gatherers of the Maghreb: the Capsian (10,000 B.P. to 6000 B.P.), Journal of World Prehistory 18(1): 57-105.

Reimer, P.J., Baillie, M.G.L., Bard, E., Bayliss, A., Beck, J.W., Bertrand, C., Blackwell, P.G., Buck, C.E., Burr, G., Cutler, K.B., Damon, P.E., Edwards, R.L., Fairbanks, R.G., Friedrich, M., Guilderson, T.P., Hughen, K.A., Kromer, B., McCormac, F.G., Manning, S., Bronk Ramsey, C., Reimer, R.W., Remmele, S., Southon, J.R., Stuiver, M., Talamo, S., Taylor, F.W., van der Plicht, J. and Weyhenmeyer C.E. (2004), IntCal04 terrestrial radiocarbon age calibration, 0-26 cal kyr BP. Radiocarbon 46:10291058 .

Roubet, C. (1979) Economie Pastorale Préagricole en Algérie Orientale: Le Néolithique de Tradition Capsienne. Centre National de la Recherche Scientifique, Paris.

Sheppard, P. (1987) The Capsian of North Africa: Stylistic Variation in Stone Tool Assemblages. British Archaeological Reports, International Series 353, Oxford. 
Sheppard, P. (1988) The lithic assemblage. Unpublished manuscript prepared for publication in Lubell, D., Jackes, M., Sheppard, P., Farrand, W.R. and others, Early to mid-Holocene subsistence and settlement in the Telidjene Basin, eastern Algeria (in preparation).

Stager, J.C. and Mayewski P.A. (1997) Abrupt early to mid-Holocene climatic transition registered at the Equator and the poles. Science 276: 1834-1836.

Street-Perrott, F.A. and Perrott, R.A. (1993) Holocene vegetation, lake levels, and climate of Africa. In Wright, H.E. Jr., Kutzbach, J.E., Webb, T. III, Ruddiman, W.F., Street-Perrott, F.A. and Bartlein, P.J. (eds.), Global Climates Since the Last Glacial Maximum, University of Minnesota, Minneapolis, pp. 318-356.

Stuiver, M. and Reimer, P.J. (1993) Extended (super 14) C data base and revised CALIB 3.0 (super 14) C age calibration program. Radiocarbon 35: 215-230.

Tixier, J. (1976) L'industrie lithique Capsienne de l'Aïn Dokkara (Région de Tébessa, Algérie). Libyca 24: 21-54,

Vaufrey, R. (1936) Stratigraphie capsienne. Đwiatowit 16: 15-34.

Vernet, R. (1995) Climats anciens du Nord de l'Afrique, L'Harmattan, Paris.

Wengler, L. and Vernet, J-L. (1992) Vegetation, sedimentary deposits and climates during the Late Pleistocene and Holocene in eastern Morocco. Palaeogeography, Palaeoclimatology, Palaeoecology 94: 141-167.

Zielhofer, C., Faust, D., Baena Escudero, R., Diaz del Olmo, F., Kadereit, A., Moldenhauer, K-M. and Porras, A. (2004) Centennial-scale late-Pleistocene to mid-Holocene synthetic profile of the Medjerda Valley, northern Tunisia. The Holocene 14 (6): 851-861. 